\title{
Vulnerability of the coastal zone of The Gambia to sea level rise and development of response strategies and adaptation options
}

\author{
Bubu P. Jallow ${ }^{1}$, Malang K. A. Barrow ${ }^{2}$, Stephen P. Leatherman ${ }^{3}$ \\ ${ }^{1}$ Department of Water Resources, 7 Marina Parade, Banjul, The Gambia \\ ${ }^{2}$ National Environment Agency, 5 Fitzerald Street, Banjul, The Gambia \\ ${ }^{3}$ Laboratory for Coastal Research, Department of Geography, University of Maryland, 1113 LeFrak Hall, \\ College Park, Maryland 20742, USA
}

\begin{abstract}
The coastal zone of The Gambia consists of $70 \mathrm{~km}$ open ocean coast and $200 \mathrm{~km}$ sheltered coast. Only about $20 \mathrm{~km}$ of the open coastline is significantly developed and this includes Banjul (the capital city), Bakau and Cape St. Mary, Fajara and the Tourism Development Area (TDA). Tourism is the most important economic sector in the coastal zone and contributes about $10 \%$ of the government revenue. Fisheries and agriculture are also important coastal industries. In this study the Aerial Videotape-assisted Vulnerability Analysis (AVVA) technique has been used to provide a detailed analysis of vulnerability to sea level rise, and adaptation strategies have been identified. The data used includes a video recording of the coastline, color infrared and black and white aerial photography, topographic maps, bathymetric maps, a geological map of The Gambia and still photographs. The data have been used to characterize the coastal zone into 9 geomorphological units, wherein the cultural and heritage sites of economic importance have been delineated and characterized according to their biophysical and economic importance. Future erosion rates have been projected by applying the Bruun Rule, and future total land loss due to inundation in response to global warming and accelerated sea level rise has been determined. The sea level rise scenarios considered are $0.2 \mathrm{~m}, 0.5 \mathrm{~m}$, and $1.0 \mathrm{~m}$ per century. Inundation is estimated to be about $92.32 \times 10^{6} \mathrm{~m}^{2}$ for a $1.0 \mathrm{~m}$ sea level rise, $45.89 \times 10^{6} \mathrm{~m}^{2}$ for a $0.5 \mathrm{~m}$ sea level rise and $4.96 \times 10^{6} \mathrm{~m}^{2}$ for a $0.2 \mathrm{~m}$ sea level rise. The greater part of this area lost will be wetlands and mangrove systems important for fish spawning areas and habitats for wildlife. Shoreline retreat is estimated to vary between about $6.8 \mathrm{~m}$ in cliffy areas to about $880 \mathrm{~m}$ for more flat and sandy areas based on the Bruun Rule. Population and physical structures at risk have been determined. Attempts have been made to report this loss in monetary terms, but firm figures are not yet available. Only one unit of the coastal zone has been evaluated. In this unit, it is expected that the capital city will be completely lost through both erosion and inundation within 50 to $60 \mathrm{yr}$ with a total of 42000 persons displaced. Lands and physical structures to be lost are estimated at US\$ 217 million. Response strategies and adaptation options identified include: innovative sand management, building and rehabilitation of groins, construction of revetments to protect important areas, construction of sea-walls/bulkheads, public outreach and awareness, building regulations and urban growth planning, wetland preservation and mitigation, and development of a coastal zone management plan.
\end{abstract}

KEY WORDS: Coastal vulnerability $\cdot$ Sea level rise impacts $\cdot$ Gambian coast

\section{INTRODUCTION}

The coastal zone of The Gambia extends from Buniadu Point and the Karenti Bolong in the north to the mouth of the Allahein River in the south (Fig. 1). The Gambia has $70 \mathrm{~km}$ of open ocean coast and about $200 \mathrm{~km}$ of sheltered coast along The Gambia River and is bounded on both sides by Senegal. The sheltered coast is dominated by extensive mangrove systems (66900 ha: 15000 ha of high mangroves and 51900 ha of low mangroves) and mud flats.

Only about $20 \mathrm{~km}$ of the coastline is significantly developed and this includes Banjul (the capital city), Bakau and Cape St. Mary, Fajara and the Tourism 


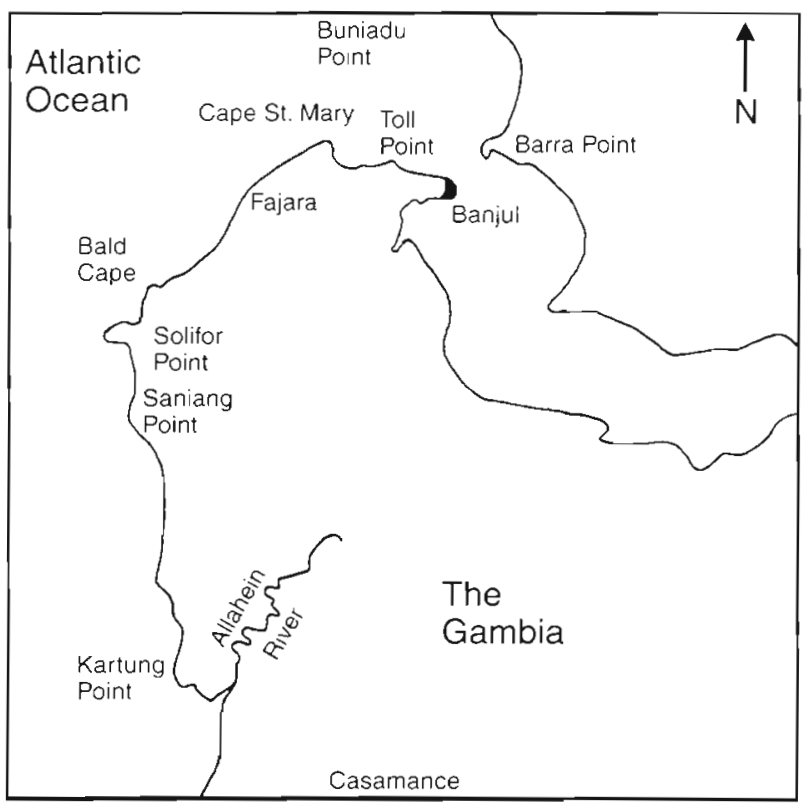

Fig. 1. The Gambia, West Africa

Development Area (TDA). Thirteen hotels and tourist resorts have been built on this stretch of the coastline. Elsewhere, the coastline is largely underdeveloped except for some fish landing sites and cold storage infrastructure used to process and store fish and shrimp.

All the storms affecting The Gambia come from the east, and the wind blows offshore at between 35 and 60 nautical miles per hour (knots). Interestingly, when these storms, known as the West African disturbance lines or squall lines, survive the energy-depleting cool Canary Current of the West African coast and move into the relatively warmer ocean water at about $28^{\circ} \mathrm{W}$ longitude, they become energized and can develop into hurricanes, entering the Caribbean and impacting the United States coasts. These storms produce about $70 \%$ of the annual rainfall in the Sahel region of West Africa (including The Gambia).

The coastal zone contributes significantly to the economy of The Gambia. During the period of October to May, when clear skies and dry weather dominate, The Gambia receives more than 100000 tourists; all beach resorts and hotels are operational, and the industry employs about 7000 persons either directly or indirectly. It is estimated that in 1990/1991 the Government collected about 48 million Gambian Dalasis (US\$ 5.3 million) in direct and indirect taxes from tourism, which amounts to about $10 \%$ of government revenue (UNEP 1992).

Another important sector of The Gambian economy in the coastal zone is fisheries. In 1990, 1500 artisanal fishing boats and 71 industrial vessels operated in The
Gambia, and exports were estimated at US\$ 2.3 million

Agriculture, especially horticulture, is of increasing importance in the coastal zone with export of vegetables and flowers to Europe. However, a decrease in aquifer recharge due to about $20 \mathrm{yr}$ of drought and over-exploitation has led to slight salinization of the ground water supply in the capital city of Banjul and lowlands adjacent to the mangrove systems between Banjul, Bakau and Old Jeswang. In the 1970 s the borehole supplying Banjul was sealed off primarily due to salinization, and water is now pumped through pipes from Cape St. Mary (Fig. 1). Sea level rise is expected to exacerbate salinization in these areas, but this major problem already exists today.

Sea level rise will have a major impact on The Gambia because so much of the economic activity, including the capital city, and major population centers are located in the coastal zone. The purpose of this research was to estimate the impact of a $0.2 \mathrm{~m}$ (baseline), $0.5 \mathrm{~m}$ and $1.0 \mathrm{~m}$ rise in sea level on the Gambian coast, including the potential effect on coastal infrastructure. The AVVA technique, as described below, was used to conduct the vulnerability analysis as prescribed by the IPCC (1990). Because much of the coastal area, including the capital city of Banjul, is built on low-lying, erodible sediments and subject to both erosion and inundation, both adaptation and mitigation strategies must be employed. Banjul must be protected at all cost, while elsewhere development should be guided away from the most vulnerable areas as identified in this analysis.

Various data sets on the coastal zone of The Gambia were assembled to inventory and characterize the study area. The data and information collected included black and white aerial photographs for 1972 (scale of 1:25000) and 1982 (scale of 1:50000) color infrared (CIR) photographs for 1993 at a scale of $1: 25000,1976$ topographic maps at a scale of $1: 10000$ with a contour interval of 5 feet $(1.52 \mathrm{~m})$. By comparison, the United States Geological Survey (USGS) topographic map series are at 1:25000, and the contour intervals range from 5 to 20 feet. Also available are contoured orthophoto maps of the 1982 aerial photography at a scale of 1:10000 and bathymetric maps of part of the coastline and the River Gambia at a scale of 1:75000. Still photographs from different years showing some of the damage caused by erosion were taken along the developed coast. A geological map of The Gambia at a scale of 1:250000 was also available. Therefore, The Gambia has an excellent data base for sea level rise impact study and analysis.

Especially for this study, a low-level aerial video record of both the open and sheltered coasts was acquired. The video record was obtained as part of the 
AVVA, which is a new, rapid and low-cost reconnaissance technique that involves the combination of (1) obliquely videotaping the coastline at low altitude from a small airplane, (2) limited ground-truth measurements, and (3) archival research (Leatherman et al. 1995). From the video record it is possible to determine the type of coast, land use, land cover, and infrastructure.

Sources for socioeconomic change data included Gross Domestic Product (GDP) and Gross National Product (GNP) values for the last $20 \mathrm{yr}$ as well as population and population density in the study area, annual number of tourists visiting The Gambia, out-ofpocket expenditures for hotels, and planned tourism development. Information on fish landings and catch by species, wetland habitats, and historic and cultural assets were also available.

\section{COASTAL CHARACTERISTICS}

The subsurface geology of The Gambia consists almost entirely of nearly flat-lying sedimentary beds, dipping gently and also thickening gradually to the west (Whyte \& Russel 1988). During an earlier high stand of the sea, rias formed along the lower portion of the River Gambia, the Niji Bolong, and the Allahein and Tanji Rivers. Today this area is characterized by a depositional strand-plain ranging in width from 200 to $400 \mathrm{~m}$ in the Batokunku area and from 500 to $800 \mathrm{~m}$ in the Saniang and Kartung areas. Therefore, beach erosion in response to sea level rise will not be a problem in these areas.

Most of the beaches consist of medium to fine, white, well-sorted sand comprised of nearly pure quartz grains. Other beaches are characterized by concentrations of cockle (Acra senelis) shells, resulting in a wellsorted yellow sand. Beaches are often bounded by rocky headlands, composed of sandstone and laterite rock. Large blocks of sandstone or laterite lie scattered in the near-shore, as at Saniang, Cape Point and Solifor Point. These blocks also occur as offshore islands such as the Bijilor Islands.

The Banjul spit is considered to be a Holocene-age feature. The upper $4 \mathrm{~m}$ consists predominantly of sand, with isolated bands of clay. At $4 \mathrm{~m}$ depth a compact fine to very fine sand occurs, and below 7 to $8 \mathrm{~m}$ of clay dominates. Therefore, the capital city has been constructed on a low-lying barrier landform that is entirely composed of erodible sedimentary materials.

The study area was divided into 9 units on the basis of their geomorphic characteristics and vulnerability to sea level rise impacts. Some of these delineations are based on the UNEP/OCA PAC Report (Quelennec 1988).

\section{Buniadu Point/Kerenti Bolong to Barra Point (Unit 1)}

This coastal unit (Fig. 1) exhibits a strand-plain type of coast consisting of sandy barriers and beach ridges. Extensive mangrove systems border the coastline south of the Kerenti Bolong and in the immediate vicinity of the Senegal-Gambia border. These wooded wetlands are useful as habitats for birds and for provision of timber for construction and fuelwood. The systems are also important as fish spawning grounds.

Two settlements are located on the banks of the Massarinko and Niji Bolongs, but at a safe distance from the direct effects of the sea. A holiday resort has been built at the shoreline with no protection from the sea.

\section{The River Gambia estuary (Unit 2)}

The River Gambia is about $11 \mathrm{~km}$ wide between Cape St. Mary and Buniadu Point and about $4 \mathrm{~km}$ wide between Banjul and Barra (Fig. 1). It narrows down to about $1.5 \mathrm{~km}$ at Carrol's Wharf (about $200 \mathrm{~km}$ inland). The extensive mangrove systems and mud flats flanking the River Gambia are important for spawning and as habitats for aquatic species. Fish and shrimp from these wetlands provide the population with their daily protein supply. Shrimp farming (aquaculture) is becoming very important and is a growing export commodity. The mud flats and adjacent low marshy lands are also used for rice cultivation.

In this wave-sheltered environment, mangroves have spread directly into accreting tidal mudflats. They are backed by unvegetated salt marshes with savannah hinterland. Some areas have been reclaimed for aquaculture and rice production. Die-back of mangroves has been identified in some areas, particularly in the delta area and the Bintang Bolong. This may be due to reduction in sediment supply, resulting from damming of some tributaries in Senegal.

Heights of tides are given above datum level at Banjul. The datum level is zero on the automatic tide gauge on Government Wharf, or $2.9 \mathrm{~m}$ below a beachmark cut beneath the top of the concrete pile supporting the southwest corner of the wharf. Water levels from records taken at Banjul Wharf are shown in Fig. 2. The height of tide is greatly influenced by the prevailing weather. A consistently strong westerly wind has been known to increase the height of tides and thereby the rate of the stream flow (GPA 1991), but storm surges are not generated even during the height of the rainy (storm) season. Unfortunately, the tide record is too short to infer any trend in local sea level. 


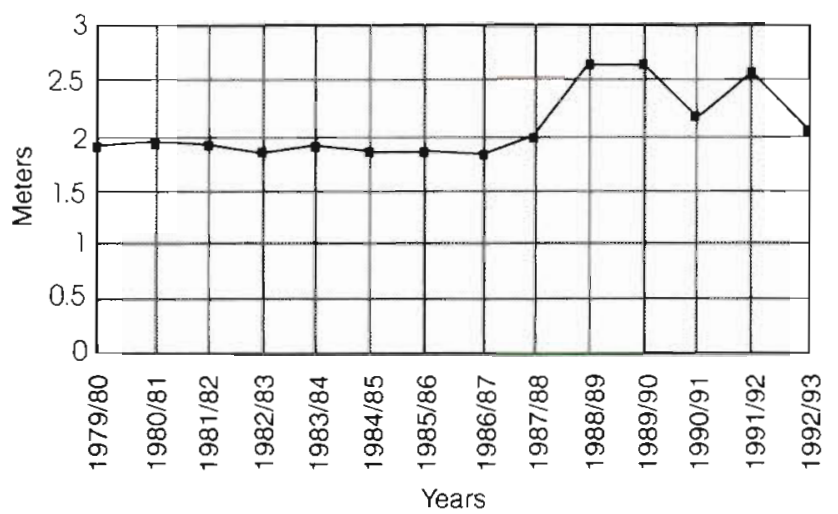

Fig. 2. Maximum water levels (m above datum level) at Banjul Wharf, The Gambia

\section{Banjul to Cape Point (Unit 3)}

The coastline within this unit includes Banjul with a population of about 42000 inhabitants. All government ministries and most departments are located in Banjul. Important cultural and heritage sites (Banjul National Cemetery and some shrines), 7 hotels, and a vegetable oil mill, a private radio station, 5 ice plants, and fish and shrimp processing and storage plants are located on this shoreline. The most expensive highway ever constructed in The Gambia with a total distance of $12 \mathrm{~km}$, runs parallel to this coastline and presently is as close as $10 \mathrm{~m}$ from the high water line at some points. The total cost has been estimated at about 83 million Dalasis (US\$ 10.4 million), which is about US\$ 1 million per $\mathrm{km}$. This area experiences net long-shore sediment transport from Cape St. Mary eastward toward the

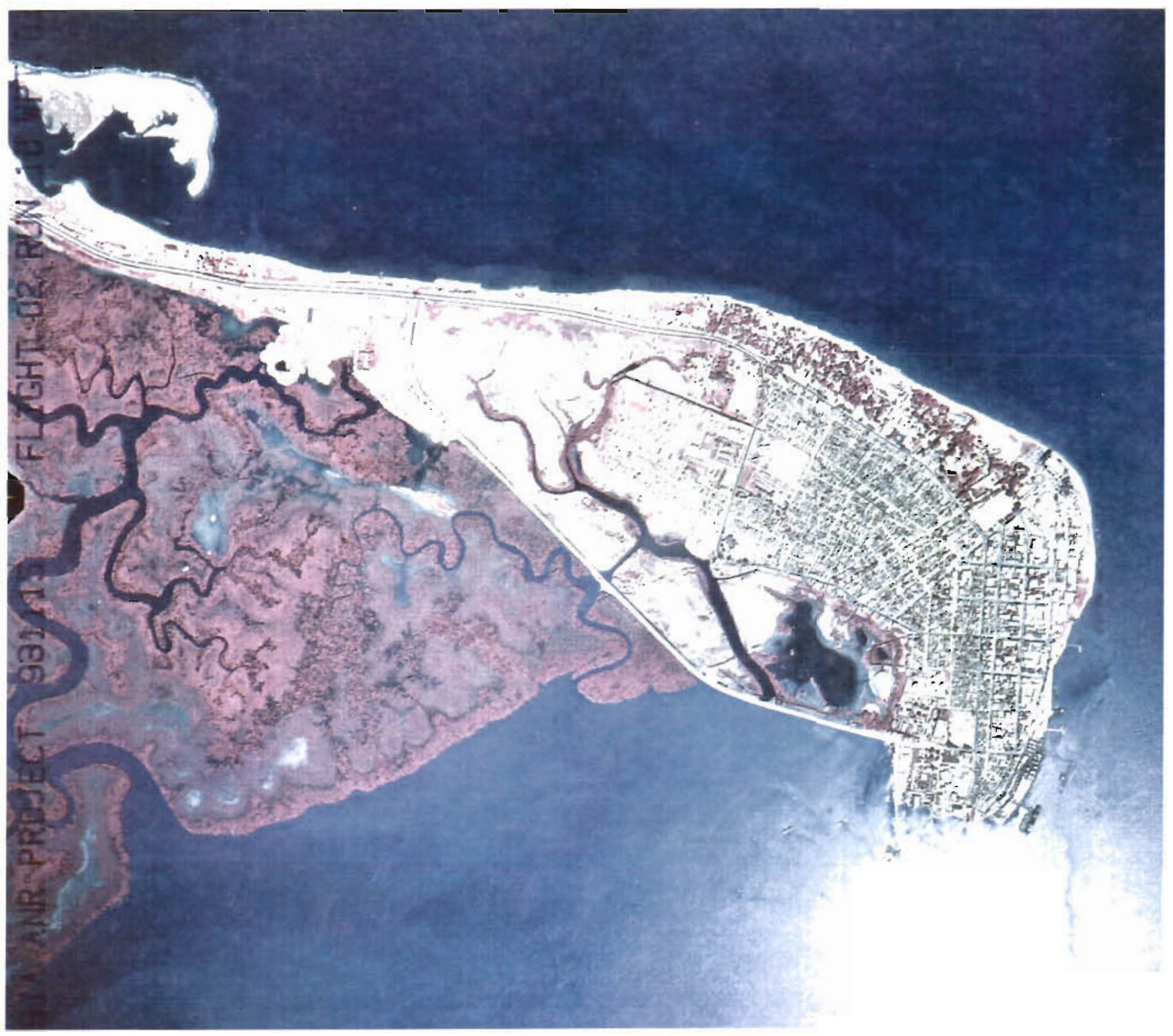

Fig. 3. Banjul, the capital city of The Gambia, was built on a low-lying sand spit 


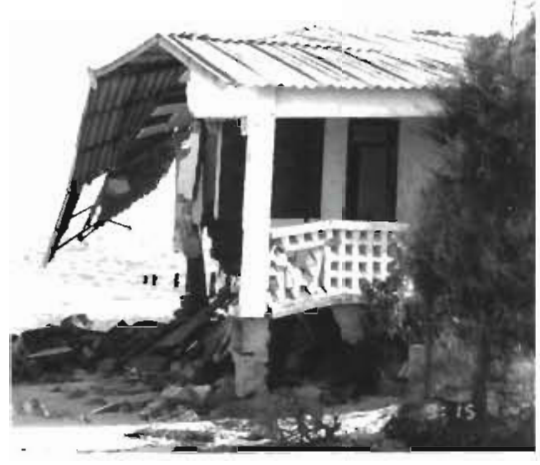

Fig. 4. Houses are damaged due to continued beach erosion in Unit 3, Banjul to Cape Point
River Gambia, and the dominant waves come from the west and southwest. Barrier spit and island systems (Fig. 3) trend eastward into The Gambia River and are the main geomorphological features in this unit. Banjul, with the highest point about $2 \mathrm{~m}$ above mean sea level, has been built on the largest recurved sand spit ( 1.6 by $1.2 \mathrm{~km}$; Fig. 3) at the terminus of the long-shore sediment transport system.

Between the Banjul Cemeteries and Mile 2 Central Prison is an area of significant erosion, and the erosion rate is reported to have increased in recent years. Structural damage is a continuing and growing problem (Fig. 4) in this area. Just updrift (to the west) of Mile 2 is a promontory or headland (Toll Point, Fig. 5)

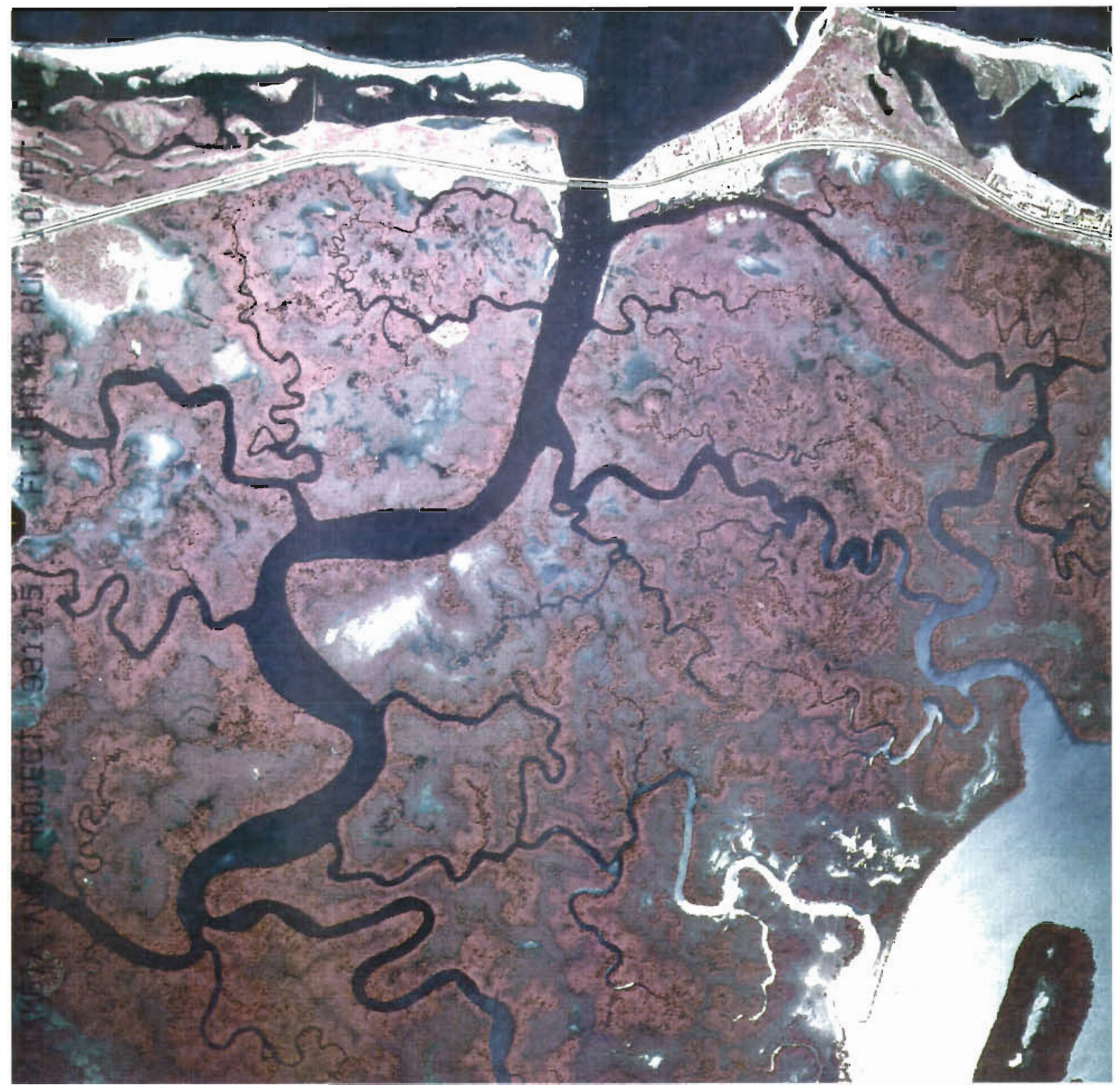

Fig. 5. This 1993 aerial photo shows the growing sand spit at Toll Point (west of Banjul) and indicates the demise of mangroves (white spots) 
that is rapidly eroding and forming a sand spit extending $50 \mathrm{~m}$ eastward. It encloses an enlarging lagoon with an open outlet to the east. This spit accretion has been occurring at least for the past 20 to $30 \mathrm{yr}$ based on comparison of historical aerial photos. During low tide local people and some tourists from the nearby hotels can be seen picking oysters from this lagoon. Some fishing is also carried out in the lagoon at high tide. The whole area is also important for wind surfing during the tourist season (October-April). Presently this sand spit is sand-starving the downdrift shoreline, accelerating the erosion problem at the cemetery. Using spot measurements on the 1972 and 1993 aerial photography, the coastal erosion rate in this area has been assessed at about $2.5 \mathrm{~m} \mathrm{yr}^{-1}$.

To the west of Toll Point (the headland) is the Oyster Creek River and bridge. A barrier island, about $5 \mathrm{~km}$ long, and a system of tiny, sandy spits and offshore bars extend from Oyster Creek to Cape Point. Cape Point sits on hard bedrock and is protected from the offshore wave activity.

\section{Cape Point to Fajara (Unit 4)}

Here the coastline is characterized by actively eroding cliffs, and protective measures have been taken to stabilize the cliffs at some places. The stabilization measures include concrete-type structures built from the waterline to about a third of the height up the cliffs.

Cliff erosional processes are mainly due to direct wave action on loose cliff material when large waves occur at high tide. This induces slope failure and landslides, which are especially visible between the Medical Research Park and the Tropic Garden Hotel at Bakau. The same erosional processes act on the Fajara cliffs further west.

A fish landing and smoking site is located on the shoreline below the cliffs and on one of the pocket beaches. This area includes 3 hotels, the official residence of the former president, residences of ambassadors and heads of diplomatic missions in The Gambia, the Department of Agricultural Services, and expensive personal residences of most of the rich Gambians. Land in the Fajara area and on the Kairaba Avenue leading to the area is allocated to those that can afford to build prescribed (large) houses.

\section{Fajara to Bald Cape (Unit 5)}

Kololi Point is a prominent geomorphological feature in the northern part of this unit, and shoreline recession is evident by the wave-cut cliffs. Between Bijilo Forest Park and the Brufut fish landing sites, wave-cut, sandy cliffs reach a height of about $30 \mathrm{~m}$ in some locations. Immediately north of Bald Cape, the shoreline is very unstable. Sand spits develop and disappear at the Cape. The Cape is protected by rocky outcrops which are visible at low tide (Fig. 6).

Eight hotels and tourist resorts have been built on this shoreline and include the famous and luxurious fivestar Kairaba Hotel. Bijilo Forest Park is located on the cliffs to the northwest of Bijilo. The Brufut fish landing and curing site is situated to the west of Ghana town, a settlement established by some tribes from Ghana whose main occupation is fishing and fish processing.

\section{Bald Cape to Solifor Point (Unit 6)}

Perhaps the most interesting geomorphological feature within this unit is a sand spit at the mouth of the Tanji River. Because large supplies of sand are available, the shore is still accreting. The 1993 aerial photography (Fig. 6) shows that the Tanji River recently has cut the sandy spit in half in order to reach the Atlantic Ocean. Therefore, coastal erosion will not be a problem for this unit.

\section{Solifor Point to Bench Mark KM125 (Unit 7)}

This long, undeveloped strand-plain type of coast rises from the beach to meet a cliffy zone, which is an ancient, wave-cut cliff, delineating an earlier shoreline. This wide strand-plain is accretionary, and hence sea level rise will have little impact on this area.

South of Saniang Point the strand-plain is even more expansive, and the Kakima River is virtually cut off from the ocean by accumulating sand. Only during floods and high tide can the river empty into the ocean. Fish landing and curing at Batokunku and cultivation of rice in the upper reaches of the Kakima and Benifet Rivers are important economic activities here.

\section{Bench Mark KM125 to Kartung Point (Unit 8)}

The Gunjur fish landing and curing site and the Kafaya beach resort are the only important landmarks in this unit. An ice plant and cold storage facilities are installed on the top of the sand dune, tens of meters from the shoreline. At the Kafaya beach resort, waves are observed to undercut the foot of the dunes, an indication that this area is directly exposed to wave action during storms. Erosional problems in response to rising sea level can be expected in the near future.

Kartung Point (Fig. 7) is the northern tip of a growing triangular-shaped strand-plain that is sheltering the 
village of Kartung from the direct effects of the ocean. Vegetable gardening and rice cultivation are carried out on this plain, which will be little impacted by erosion. Inundation, however, could affect the agricultural activities.

\section{Kartung Point to Allahein River (Unit 9)}

This is the southern end of the Gambian coastline and terminates at the mouth of the Allahein River. A series of dynamic sand spits and beach ridges runs parallel to the shore from Kartong Point to the mouth of the river (Fig. 7). This strand-plain, about $2.5 \mathrm{~km}$ wide, is low-lying with extensive mangroves, the greater part being less than $1 \mathrm{~m}$ above mean sea level. Therefore, inundation in response to rising sea level could be a problem in the future, but this area is largely unpopulated.

\section{IMPACTS OF A 1 M SEA LEVEL RISE ON THE GAMBIAN COASTAL ZONE}

\section{Methodology}

The impacts assessment procedure followed the AVVA technique. In this study video recording was combined with aerial photography for 1972 and 1993 1976 topographic maps at a scale of 1:10000, and other socioeconomic and land-use data described above.

From the video record it is possible to determine the type of coast, level of land development, landuse type and infrastructure. Combining the video record and the historical data, it was possible to assess both qualitatively and quantitatively some of the potential impacts of a sea level rise up to $1 \mathrm{~m}$ based on IPCC scenarios.

Of primary concern was to determine how much land would be lost in response to a $1 \mathrm{~m}$ sea level rise. This is made possible through the use of the Bruun Rule for estimation of retreat through beach and dune erosion. We assumed that sea level rise is the only forcing factor that will bring about the change and then estimated land loss for each of the sea level rise scenarios. For low-lying areas not subject to oceanic waves, land loss can result from direct inundation or permanent submergence.

Having determined the land lost due to erosion and inundation, the impacts of this loss on all the major socioeconomic sectors of the country are evaluated. The losses and impacts are then expressed in monetary terms and extrapolated with time. Adaptation options and response strategies are then assessed and costed and the most viable option is selected. The results of this study will be used to develop a Coastal Zone Management Action Plan.
Details of the AVVA technique and its applicability can be found in Leatherman et al. (1995), while the methodology for the estimation of land loss and response options is detailed in Nicholls et al. (1995).

\section{Sea level rise scenarios}

Tide gauge records available in The Gambia cover only a short period of time with some missing data. The trend indicated by analysis of these data is statistically insignificant. Long-term geological data also suggest insignificant tectonic variations. Hence the global sea level rise scenarios that have been widely adopted (IPCC 1990, Pepper et al. 1992) are used. These scenarios are the current rate of sea level rise of $0.2 \mathrm{~m}$ (no acceleration), $0.5 \mathrm{~m}$, and $1.0 \mathrm{~m}$ per century. Where the variation of the land formation is relatively smooth, the $0.5 \mathrm{~m}$ contour of land inundation is interpolated from the $1.0 \mathrm{~m}$ contour line on the coastal map series.

\section{Estimation of land loss on the open coast due to inundation}

Mangrove swamps and other low land types exist in the Massarinko and Niji Bolongs on the north bank, the Kotu stream, and the Kakima, Benefiet and Allahein Rivers on the south bank. The area likely to be inundated was delineated on the topographic maps by estimating the $1 \mathrm{~m}$ contour line. The video recording and the aerial photography were useful in identifying where these areas exist, but were not very useful in determining elevation. Land loss due to the lower sea-level rise scenarios was estimated by linear interpolation from the amount of loss due to the $1 \mathrm{~m}$ sea level rise.

This interpolation, however, took into account the varied response of mangrove systems to sea level rise. Mangroves can accrete vertically if subjected to a slow rate of sea level rise but will be inundated if the rate of sea level rise is accelerating above a certain threshold. This threshold is site-specific and depends on factors such as availability of sediment, salinity, biomass production, cultivation and preservation.

The 1982 forest inventory in The Gambia showed a decline in the area of mangroves, and this finding is confirmed by the 1993 aerial photography (Fig. 5), which shows significant die-back and in some areas total loss of trees. This loss could be attributed to reduction in sediment availability due to damming of some of the tributaries of The Gambia in Senegal and increase in salinity due to a decline in recharge of the ground water as a result of the Sahelian drought.

Therefore, we assumed that $0.2 \mathrm{~m}$ century ${ }^{-1}$, which is the present eustatic rate of sea level rise, is a threshold 


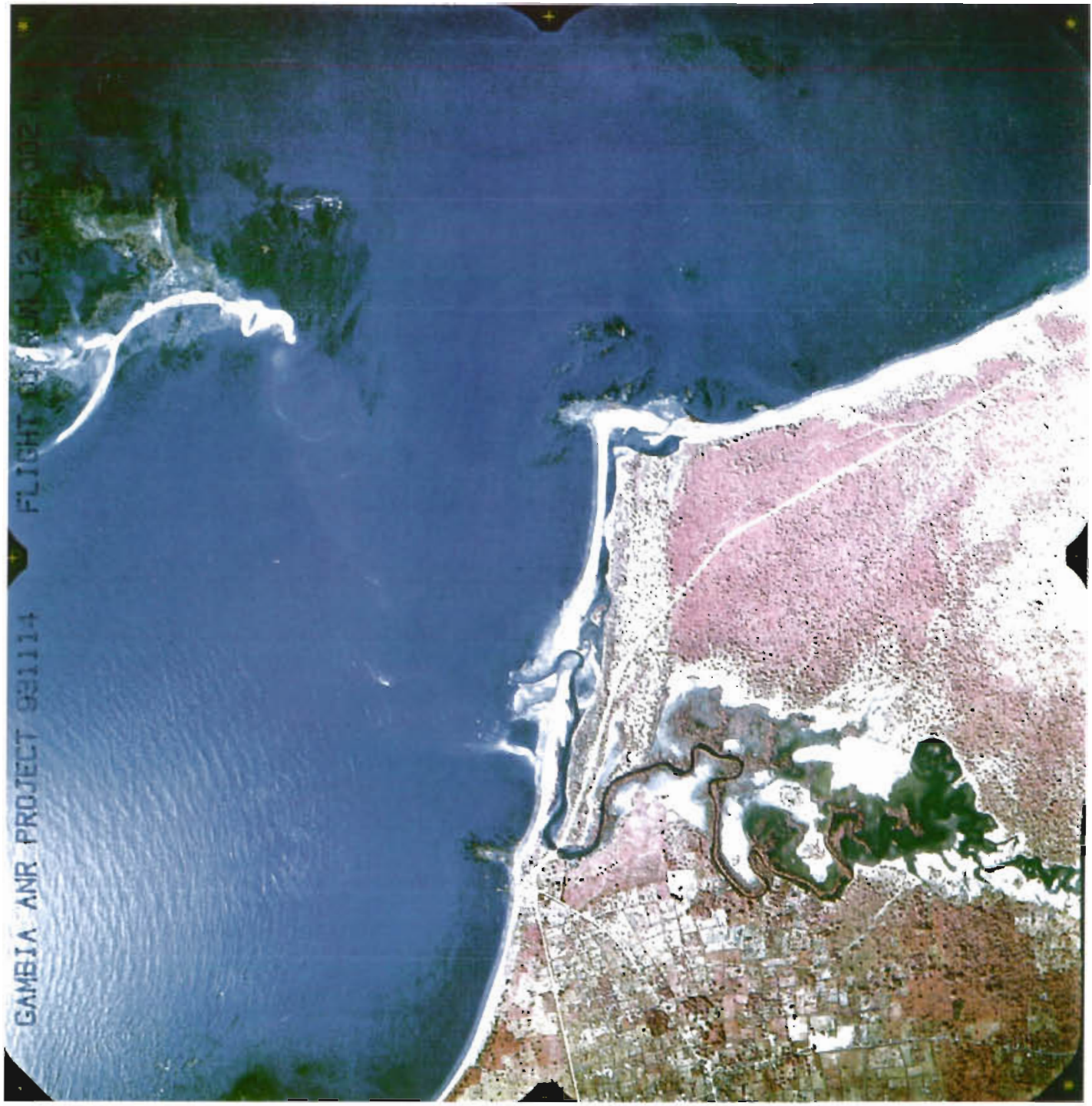

Fig. 6. Rocky outcrops about $400 \mathrm{~m}$ offshore of Bald Cape (shown here), if submerged by rising sea level, could result in significantly higher wave energy being exerted on this coast, which has been heavily developed with expensive beach-front hotels

for Gambian mangroves, and that a $1 \mathrm{~m}$ century ${ }^{-1}$ rise would result in the total loss of mangroves in The Gambia. The percentage loss for intermediate scenarios $(0.5 \mathrm{~m})$ was then linearly interpolated. Table 1 shows the potential area to be lost as a result of the various sea level rise scenarios due to predicted climate change.

\section{Beach erosion on the open coast}

Hands (1983) gives the mathematical definition of the Bruun Rule as

$$
R=G\left[L /\left(B \cdot h^{\bullet}\right)\right] S
$$

where $R$ is the retreat (erosion rate) due to a sea level rise $S$ (scenario) above mean sea level, $h^{*}$ is the depth of closure, $B$ is the dune/cliff height, $L$ is the width of the active profile, and $G$ is the inverse of the overfill ratio of the material being eroded. It is reasonable to assume that all the eroded material will remain within the active beach/nearshore profile because sand is predominant on the open ocean coast. The implication of this assumption is that $G$, the overfill ratio, can be safely taken to be equal to 1 . Where this assumption is not valid, meaning some of the eroded material is lost to deeper water because it is fine-grained (clay and silt). greater recession than reported would be expected

The depth of closure, $h^{*}$, is difficult to estimate as there are no accepted methods for estimating it over long time scales. Dennis et al. (1995) in their estimation 


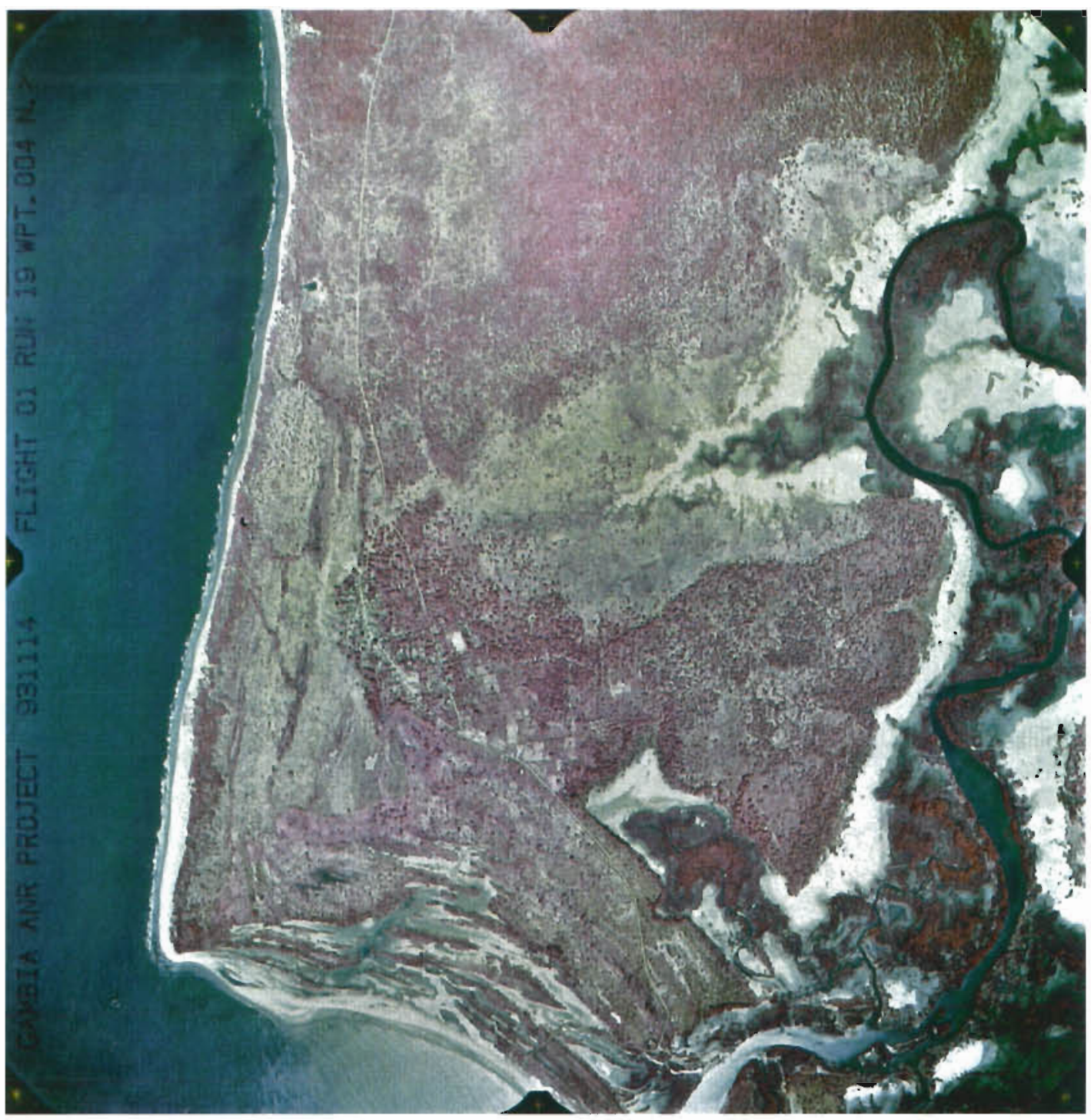

Fig. 7 Kartung Point to Allahein River (Unit 9) is an accretionary strand-plain that would be little affected by sea level rise impacts

Table 1. Area $\left(\mathrm{m}^{2}\right)$ of land to be lost in The Gambia in response to various sea level rise scenarios

\begin{tabular}{|c|c|c|c|}
\hline \multirow[t]{2}{*}{ Coastal unit } & \multicolumn{3}{|c|}{ Sea level rise scenarios (m century ${ }^{-1}$ ): } \\
\hline & 0.2 & 0.5 & 1.0 \\
\hline Senegal border (north) to Barra Point & 562500.0 & 14062500.0 & 28125000.0 \\
\hline River Gambia estuary & 937500.0 & 23437500.0 & 46875000.0 \\
\hline Banjul Point to Cape St. Mary & 1560000.0 & 3900000.0 & 7800000.0 \\
\hline Cape St. Mary to Fajara & 0.0 & 0.0 & 0.0 \\
\hline Fajara to Bald Cape & 10000.0 & 25000.0 & 50000.0 \\
\hline Bald Cape to Solifor Point & 406000.0 & 1015000.0 & 2030000.0 \\
\hline Solifor Point to Bench Mark KM125 & 268000.0 & 670000.0 & 1340000.0 \\
\hline Bench Mark KM125 to Kartung Point & 34000.0 & 085000.0 & 170000.0 \\
\hline Kartung Point to Senegal border (south) & 1186000.0 & 2695000.0 & 5930000.0 \\
\hline Total land loss & 4964000.0 & 45890000.0 & 92320000.0 \\
\hline
\end{tabular}


of the potential impacts and consequences of sea level rise in Senegal used the low and high estimates of closure depth, which according to Nicholls et al. (1995) will embrace the actual depth of closure. They used 2 boundaries, depth of closure for the first year of the analysis $\left(h^{*}{ }_{L, 1}\right)$ and depth of closure over a century $\left(h_{L .100}\right)$. The depth of closure for the 100 yr period was calculated from the annual depth of closure as

$$
h_{L, 100}^{*}=1.75 h_{L, 1}^{*}
$$

and they then referenced the depths to a datum $1 \mathrm{~m}$ above low water.

From the results of their calculation they reasonably assumed $h^{*}{ }_{L, 1}$ and $h^{*}{ }_{\text {L, } 100}$ as 3.4 and $5.9 \mathrm{~m}$, respectively, for the low wave energy sector from Dakar to Bissau. Since the Gambian coastline is within this southern sector, these values are used in the applications of the Bruun Rule in this study, but the derived values of coastal retreat may be slightly high for the rivermouth protected coast of Banjul.

The active profile widths $(L)$ were determined at different locations along the coast. Since the coastline of The Gambia shows varying beach width as well as dune and cliff heights, the Bruun rule is applied to similar segments following the characterization of the coastline. The coastline also consists of spits/barriers backed by marshes and mangroves and in some places strand-plain type coast. In these areas the drowning (inundation) concept of land loss was used to estimate the initial potential impact for the first half of the period $(50 \mathrm{yr})$ in question. After inundation, the remaining land will be subject to wave action and so the Bruun Rule is applied for the second half of the analysis period.

Table 2 shows the results of applying the Bruun Rule to determine the retreat of land for a $1 \mathrm{~m}$ sea level rise and for the various coastal units along the Gambian coastline.

\section{Estimation of land loss in the sheltered coast of the Gambia estuary}

In the sheltered coast of The Gambia, we consider only the low-lying mangrove systems and adjacent marshlands and agricultural lowlands. These systems extend to about $200 \mathrm{~km}$ upriver from the coast, and hence wave action is not critical.

The effect of sea level rise on mangroves depends on the extent to which they continue to receive sediment. Where there is little or no sediment supply, submergence is likely to cause die-back and erosion of their seaward margins. But mangroves can still spread landward, displacing the low-lying hinterland in a natural environment.
The mangrove systems bordering Banjul, Bakau, Old Jeswang, Eboe Town, Talinding Kunjang, Fagikunda, and Abuko have all their hinterland reclaimed for settlements, and thus the mangrove fringe and the adjacent agricultural lands have become narrower and will eventually disappear as sea level rises. This will lead to a loss of a large area of wetlands and fish spawning grounds. The estimated area to be lost from this region is given in Table 1.

\section{Flooding and increase in ground water levels}

During the passage of West African disturbance lines (squall lines), the accompanying heavy downpour causes flooding mostly in the capital city, settlements established on reclaimed land in dried-up valleys and in settlements that have been developed very close to mangrove swamps and wetlands. These are also the main areas where ground water levels are high and salinity is already a problem. The areas most affected are the Half-die and Tobacco Road settlements in Banjul, parts of Bakau, Old Jeswang, Eboe Town, Tallinding Kunjang, Fagikunda, and Abuko.

The strength and frequency of tropical storms may increase due to climate change (IPCC 1990). This will lead to more flooding, and the problem may be exacerbated with sea level rise. Damage to structures such as buildings and roads will be the major effect of the freshwater flooding. Only a small percentage of the population get their water supply from hand-dug wells. But the higher water table due to sea level rise will exacerbate the existing problems of pollution.

\section{ESTIMATES OF VALUE AND POPULATION AT RISK}

A comprehensive evaluation of the economic consequence of a $1 \mathrm{~m}$ sea level rise for the entire Gambian coast was not attempted. Due to limited resources and time, this evaluation was carried out only for Unit 3 (Banjul to Cape St. Mary) of the coastal zone. This analysis was based on socioeconomic and demographic data collected in the country, particularly from the Departments of State Lands, Central Statistics and Tourism. The value and costs of damage or loss to coastal infrastructure, such as roads, were also evaluated. A quantitative assessment of wetlands was not possible as these are not valued in monetary terms. However, a quantitative assessment was conducted based on their contribution to the fisheries and tourism.

If a $1 \mathrm{~m}$ sea level rise were to occur as envisaged in this study, the whole of the capital city of Banjul would drown in the next 50 to $60 \mathrm{yr}$. This is due to the fact that the greater part of the city is below $1 \mathrm{~m}$ as shown in 
Table 2. Application of the Bruun Rule to project the rate of beach erosion along the Gambian coast in response to sea level rise -: no data

\begin{tabular}{|c|c|c|c|c|c|c|}
\hline Coastal unit & $\begin{array}{c}\text { Depth of } \\
\text { closure, } \\
h^{*}(\mathrm{~m})\end{array}$ & $\begin{array}{c}\text { Overfill } \\
\text { ratio, } \\
G\end{array}$ & $\begin{array}{l}\text { Active profile } \\
\text { width, } \\
L(\mathrm{~m})\end{array}$ & $\begin{array}{c}\text { Dune or } \\
\text { cliff height, } \\
B(\mathrm{~m})\end{array}$ & $\begin{array}{c}\text { Scenario, } \\
S(\mathrm{~m})\end{array}$ & $\begin{array}{l}\text { Retreat, } R= \\
G\left[L /\left(B \cdot h^{*}\right)\right] S \\
(\mathrm{~m})\end{array}$ \\
\hline Senegal border (riorth) to Barra Point & 5.9 & 1.0 & 2610.5 & 2.0 & 1.0 & 330 \\
\hline River Gambia estuary & - & - & - & - & - & - \\
\hline Banjul Point to Cape St. Mary & 5.9 & 1.0 & 2284.2 & 2.7 & 1.0 & 265 \\
\hline Cape St. Mary to Fajara & 5.9 & 1.0 & 1232.5 & 6.1 & 1.0 & 102 \\
\hline Fajara to Bald Cape & 5.9 & 1.0 & 2080.8 & 2.7 & 1.0 & 241 \\
\hline Bald Cape to Solifor Point & 5.9 & 1.0 & 6475.5 & 1.8 & 1.0 & 840 \\
\hline Solifor Point to Bench Mark KM125 & 5.9 & 1.0 & 5098.3 & 3.0 & 1.0 & 57 \\
\hline Bench Mark KM125 to Kartung Point & - & - & -- & - & - & - \\
\hline Kartung Point to Senegal border (south) & - & - & - & - & - & - \\
\hline
\end{tabular}

Fig. 8. The mangrove systems on St. Mary's Island, Cape St. Mary and on the strand-plains of the north bank from Barra to Buniadu Point will be lost.

The entire population of Banjul (42000 inhabitants), people living in the eastern parts of Bakau and Cape St. Mary, and the swampy parts of Old Jeswang, Kanifing Industrial Estate, Eboe Town, Tallinding Kunjang, Fagikunda and Abuko will be displaced. Preliminary analysis of the data from the Department of Lands on value of land and sample properties between Banjul and the Kololi Beach Hotel suggests that 1950 billion Dalasis (USS 217 million) of property will be lost. All the structures located on the land area from Sarro to the Banjul Cemeteries and the whole of Banjul will be lost ${ }_{i}$ it is not possible to attach monetary value to this loss of public places.
Fig. 8. Contoured map of the city of Banjul showing elevations in meters

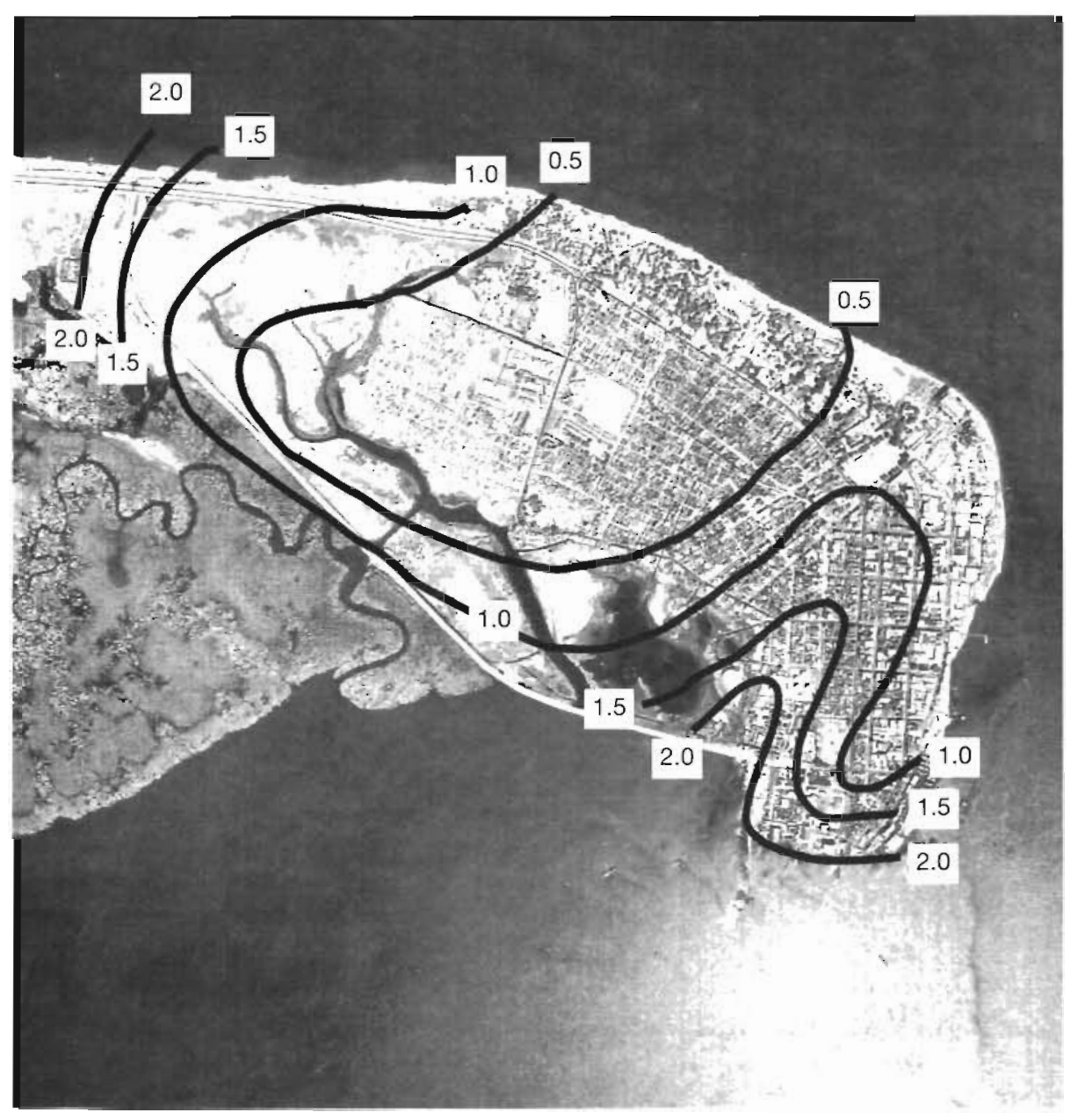




\section{RESPONSE STRATEGIES AND ADAPTATION}

If sea level rise were to accur as envisaged in this study, and considering the present economic situation of The Gambia, the most appropriate response would be to protect the important areas. These are found in Units 3 and 5 of the coastal zone. Land loss in these areas will represent about $8.5 \%$ of the total land to be lost when there is a $1 \mathrm{~m}$ rise in sea level but will represent the greatest loss to the country in economic terms.

It will be necessary to protect the whole of the coastline of Banjul, the shoreline area from the cemeteries to Wadner Beach Hotel, the infrastructure at Sarro, and the hotel complex at Cape Point.

This study has established that the area from the UHC Water Tanks to Banjul Point has been sandstarved by a growing recurved sand spit (Fig. 3). This is locally causing the large erosion problem observed in this area during the last $5 \mathrm{yr}$ in addition to the coastal retreat induced by rising sea level.

An innovative approach to solving this problem would be to tie the end of the sand spit to the mainland area around the Palm Grove/UHC Water Tanks so that it becomes a sand feed to the city of Banjul. But this will cause some problems, such as the loss of the lagoon to the west of Wadner Beach/Palm Grove Hotels. Such modifications of the long-shore sediment transport (LST) system can also eventually lead to large unwanted deposits of sand at the Banjul-Barra Ferry Terminal and The Gambia Ports Authority facilities. To protect these facilities from the huge unwanted supply of sand, a groin system can be installed to collect and hold the sand.

Groins are the principal technique of beach stabilization in West Africa, whereby trunks of rhun palm trees are jetted into the beach and tied together with timber. The existing groins in the area between Wadner Beach/Palm Grove Hotels to Banjul Point were built in the late 1950 s by the Government of The Gambia, possibly through an aid program.

Groins are easy to build, fairly cost-effective and locally hold the beach or capture more sand in the LST system. They do not 'create' new sand but merely redistribute the sand along the beach. Sand tends to be trapped on the updrift side of the groin, while downdrift erosion is accelerated. Therefore, groins must be used with a good understanding of the LST system.

Repairing these groins will help in stabilization of the beach in Banjul. To reduce the flow of sand to the Port and Ferry Terminal, a long and high terminal groin must be constructed at Banjul Point between the State House and Albert Market. This terminal groin must not be filled with sand so that the long-shore sed- iment transport is halted or reduced for some period of time

This innovative sand management and groin system to stabilize the shoreline will be useful in the short term and especially so for dealing with the erosion problem that is being faced in the area. But over the long term, it will probably be necessary to harden the shoreline along the Banjul shore in response to accelerated sea level rise.

Revetments consist of a layer of large boulders on the seaward side and a layer of filter screening material on the landward side. These 2 layers are separated by another layer of medium size gravel that is used to protect the screening material. The voids structure of the outer layer on the seaward side is used to dissipate wave energy; the filter screening material of the landward layer allows water to pass through.

Generally, the structure is built with a slope of $2: 1$ and must be designed with sea level and wave climatology in mind. When properly constructed, a revetment will stop coastal erosion but at the expense of the beach

No data are available on wave climatology so assumptions are made in order to assess the breaking wave height. We assume that during storms atmospheric pressure change may lead to a $0.2 \mathrm{~m}$ rise in the water level, prevailing winds may contribute to about $0.5 \mathrm{~m}$ rise, waves may contribute to another $0.5 \mathrm{~m}$ and the variation of tides may contribute to $0.75 \mathrm{~m}$ rise. Hence the breaking wave height may be estimate as:

$$
H_{b}=0.78(0.2+0.5+0.5+0.75)=1.52 \mathrm{~m}
$$

Therefore, it is safer to build a revetment that will be about $2 \mathrm{~m}$ high in order to avoid overtopping as sea level continues to rise over the next 50 yr (which is the lifetime of this type of structure). If the wave overtops, it digs a hole behind the filter cloth, and the whole revetment may collapse in the future

Even though the area in question is exposed to wave action, the waves are relatively small. Thus it may be necessary to build only a low-cost seawall or a bulkhead. The seawall has a $1: 2$ slope, a $2 \mathrm{~m}$ berm and a height above water of 1.2 times the sea level rise scenario.

To protect the area from the Cold Storage Plant west of the Public Works Complex (National Partnership Enterprise and Pelican) to Gambia High School and areas bordering the mangrove systems, it is sufficient to use dykes made up of about 1.5 to $2 \mathrm{~m}$ of sand, planted with vegetation.

With a $1 \mathrm{~m}$ sea level rise the shoreline from Kololi Beach Hotel to Kairaba Hotel is expected to retreat about $264 \mathrm{~m}$, which is an erosion rate of about $2.6 \mathrm{~m}$ $\mathrm{yr}^{-1}$. The area is not in immediate danger but will need to be protected either by building a revetment or a seawall in the future 
In terms of adaptation to sea level rise impacts, 4 responses should be implemented as soon as possible: public awareness, urban growth planning, wetland preservation and mitigation, and implementation of a coastal zone management plan.

\section{Public awareness}

The public should be informed about the risk of living in coastal lowlands that are at risk of being affected by sea level rise either through saltwater intrusion, flooding, or erosion. Timely public education about sea level rise impacts and risks could be a cost-effective means of reducing future expenditures. Physical planning and building control measures and regulations should be instituted and implemented

The lands, physical planning and building control institutions should avoid allocation of land that is likely to be flooded, such as the dried-up streams on the Kombo Peninsula that recently witnessed flooding during the rainy seasons of the late 1980 s.

\section{Urban growth planning}

Where the building of coastal infrastructure such as roads, fish landing and curing plants is approved and must be located on the coast, the authorities and owners of this infrastructure should make sure that marginal increases in the height of the structures are included to account for sea level rise and any other related phenomena. Siting of large capital facilities or those that pose significant hazards when flooded should not be allowed in sensitive lands and should be directed towards less vulnerable areas. People located in high-risk areas should be offered incentives to relocate out of these areas. Policies should be instituted that allow the use of high-risk areas as natural preserves or for low-value use. Marginal increases in the height of infrastructure during the construction phase and redirecting growth away from sensitive lands are relatively inexpensive options for reducing the impacts of sea level rise and risk of flooding. Policies that may lead to relocation from high risk areas will reduce the need and cost of disaster relief in the future.

\section{Wetland preservation and mitigation}

The estuary of The Gambia River contains economically important wetlands and mangrove systems. The mangrove systems on the Kombo St. Mary and Kombo Peninsula are important breeding grounds for various aquatic species. Efforts should be made to protect these areas by declaring them as protected wetlands. This would discourage exploitation of the resources in these wetlands. The possible impact of upstream dams on The Gambia River in terms of reduced sediment supply should be investigated.

\section{Coastal zone management}

Land-use planning in coastal zones, such as the use of building setbacks or allocating low-lying vulnerable lands to lower-value uses (e.g. parks rather than housing), will reduce the overall vulnerability to sea level rise. Other land-use planning mechanisms, such as construction standards, reduce the risks of living in coastal areas. Additional risk-reduction measures can be encouraged through appropriate financial mechanisms. Each of these policies reduces the risks from current climatic variability and protects against potential sea level rise impacts. When put together in the form of a program, it will constitute a Coastal Zone Management Plan.

Acknowledgements. This research was supported by the U.S Country Studies Program, Ms Sandy Guill Project Officer The authors thank Dr William C. Bolhofer and Dr Joseph Huang for their reviews, which helped strengthen this paper

\section{LITERATURE CITED}

Dennis KC, Niang-Diop I, Nicholls RJ (1995) Sea level rise in Senegal: potential impacts and consequences. J Coast Res, Spec Issue 14:243-261

GPA (Gambia Ports Authority) (1991) Tide and distance tables for Banjul and the River Gambia. GPA, Banjul

Hands EB (1983) The Great Lakes as a test model for profile responses to sea level changes. In: Komar PD (ed) Handbook of coastal processes and erosion. CRC Press, Boca Raton, p 167-189

IPCC (Intergovernmental Panel on Climate Change) (1990) Response strategies and adaptation assessment. Report of Working Group III of the IPCC, Geneva

Leatherman SP, Nicholls RJ, Dennis KC (1995) Aerial videotape-assisted vulnerability analysis: a cost-effective approach to assess sea level rise impacts. J Coast Res, Spec Issue 14:15-25

Nicholls RJ, Leatherman SP, Dennis KC, Volonte CR (1995) Impacts and responses to sea level rise: qualitative and quantitative assessments. J Coast Res, Spec Issue 14:26-43

Pepper W, Legget J, Swart R, Wasson J, Edmonds J, Mintzer I (1992) Emissions scenarios for the IPCC update. Assumptions, methodology, and results. Cambridge University Press, Cambridge

Quelennec RE (1988) Identification of coastal erosion problems in The Gambia. UNEP Report. United Nations Environmental Program

UNEP (United Nations Environmental Program) (1992) Coastal erosion in The Gambia. Prepared by Delft Hydraulics and Netherlands Economic Institute (NEI), Nairobi

Whyte WJ, Russel TS (1988) Geology and mineral resources of The Gambia 